\title{
Commodification of Foreign Languages in the Educational Space of Modern Russia
}

\author{
Veronica A. Razumovskaya* \\ Siberian Federal University \\ 79 Svobodny, Krasnoyarsk, 660041, Russia
}

Received 11.10.2015, received in revised form 20.10.2015, accepted 06.11.2015

\begin{abstract}
The main purpose of the article is to show in diachronic and synchronic aspects foreign languages teaching and learning within the educational space of Russia. A special attention is paid to English as a foreign language (EFL), the presence of which in different educational paradigms is concerned under the concept of globanglization and commodification of educational services. Both advantages and disadvantages of the linguistic learning commodification as well as the future perspectives of the linguistic lifelong learning paradigm are described.
\end{abstract}

Keywords: foreign languages learning, life long learning, the English language, globanglization, commodification.

The article is written with the financial support of the European Commission within the Tempus IV programme (Project "Lifelong Language Learning University Centre Network for New Career Opportunities and Personal Development (UNICO)", № 544283-TEMPUS-1-2013-1-ES-TEMPUSJPHES).

DOI: 10.17516/1997-1370-2015-8-11-2596-2605.

Research area: pedagogy, philology.

\section{The Brief Historical Overview of Foreign Languages Teaching in Russia}

The learning foreign languages in Russia goes hand in hand with its cultural history. A set of foreign languages in the learning community and teaching methods were clearly defined by the social demand and determined by the social, economic and political situation in the country. As the analysis of historical and pedagogical literature suggests, there are three basic periods in the history of language teaching in Russia, i.e. pre-revolutionary, Soviet and post-Soviet [Levchenko, 2013, Pavlenko, 2013]. During the period from the $14^{\text {th }}$ to $16^{\text {th }}$ century the learning was concentrated mostly in the south-west part of the Ancient Russia (Rus'), where the Kiev-Mohyla Academy and "brethren" schools of Greek, Slavic, Russian, Latin and Polish writing located. The prominence of the foreign languages in these schools is directly reflected in their names. Since the $17^{\text {th }}$ century foreign languages were mastered in the Slavic-Greek-Latin Academy, in Moscow, where people of all the social classes and ages had an opportunity to be admitted to (thus, we are speaking about a prototype of the contemporary LLL paradigm). As it is reflected by the title,

C) Siberian Federal University. All rights reserved

* Corresponding author E-mail address: veronica_raz@hotmail.com 
in the Academy the Latin and Greek languages were learnt. The further development of foreign languages education in Russia was supported by schools of different religions established in Moscow in the $17^{\text {th }}$ and the first quarter of the $18^{\text {th }}$ centuries. In Catholic and Lutheran schools, where children from both foreign and native noble families were taught, the Latin, Greek and German languages were studied. During the Petrine times $-\mathrm{a}$ watershed in the history of Russia since the country was introduced to the whole world - only certain people from the upperclass society had the knowledge of foreign languages (the German and Dutch ones). In the reign of Elizabeth of Russia the society got an opportunity to learn the French language. It is crucial that as long ago as in the $18^{\text {th }}$ century the importance of knowing foreign languages was maximized both from practical and educational sides. As the Russian teacher and principal of the Moscow University A.A. Prokopovich-Antonskii claimed in his speech delivered before the faculty and students during the solemn meeting, on June 30, in 1798: "The main advantage of our memory is in its ability to learn languages. To what do we owe such honour? They enrich us with many high and sophisticated thoughts which can either be deformed or lost in the translation. They make us citizens of the whole world, encourage spreading of trade, introduce us to the utmost nations and enable us with the ability to think about their rules, traditions, policy, science and arts either ideal or not [Antologia, 1985: 352]. In Russia a great attention was traditionally paid to the role of foreign languages studying in home education and upbringing, caused by the pursuance of the Russian elite to educate their children in the "European way". Thus, the $18^{\text {th }}$ century became a period of family tutors [Solodiankina, 2008]. It was just tutors who taught several generations of aristocrats that in fact were bilinguals: they perceived and used as the native language not only Russian but also French, and quite often, English and German. In this country of the $18^{\text {th }}$ century good skills in one or more foreign languages was an essential characteristic of an educated man. Though in that epoch the mastered languages were French and German, the interest to the English language taught in military, administrative and commercial educational institutions had also increased. In curriculums special attention was given to the methodology of the linguistic teaching. The first composite work designed for teachers of gymnasiums, private boarding schools and tutors that was dedicated to the didactics and methodology of teaching was called "The Method of Teaching" written by the professors of the Moscow University and issued in 1771. In the $18^{\text {th }}$ century the level of the linguistic culture was extremely high. Languages, first of all, brought knowledge, discovered the world for the learners, broadened their horizons, gave an opportunity to join to the world literature and to satisfy a want in reading peculiar to Russian people.

The development of the scientific ground for the foreign languages learning carried gradually during the whole $19^{\text {th }}$ century under the national schools of comparative linguistics. In colleges for noble young men and girls, in gymnasiums, cadet corps, in boarding schools foreign but adopted teaching methods were used, i.e. the grammar-translation and lexico-translation ones. In the end of $19^{\text {th }}$ and in the beginning of the $20^{\text {th }}$ century there was a so called direct or natural method also borrowed from the west tradition. In the last decades of the $19^{\text {th }}$ century living (contemporary) languages held a firm position not only in the system of higher education, but also in schools, while ancient languages were fading into insignificance. The analysis of historical and pedagogical literature allows us to think that in the Czarist-era the problems concerning foreign languages learning were in the spotlight 
of scientists, publicists, prominent political and public leaders such as V.G. Belinskii, A.I. Herzen, N.A. Dobroliubov, M.V. Lomonosov, D.I. Pisarev, N.G. Chernishevskii [Levchenko, 2013]. Within the pre-revolutionary historical period of foreign languages learning, it is of a particular importance to mention the works by K.D. Ushinskii which are dedicated to national and foreign languages teaching. The founder of the national scientific pedagogics says the following: “...the skills in foreign European languages, particularly those which are modern, can give people an opportunity of a full, individual and many-sided growth: otherwise, a wide highway of the science may well be closed for them forever. Patchiness, ambiguity, insufficiency, one-sideness, unsubstainability of facts and ideas will always weight upon a smart person in case if they do not have a key to the richness of the west science and literature [Ushinskii, 1988: 119]. In the prerevolutionary Russia, between the end of the $19^{\text {th }}$ and beginning of the $20^{\text {th }}$ the foreign languages learning took a large part of the curriculum in classical gymnasiums. Interestingly enough, the Russian language art teaching took notably less academic hours. In other educational institutions (for example, in non-classical secondary schools or seminaries) less attention was paid to foreign languages leaning, but still, twice as much as to the national one. In elementary schools, where children of lower social classes studied, foreign languages were excluded from the curriculum at all. Considering scientific and pedagogical aspects on the development of the European foreign languages teaching methodology in Russia within this historical period, L.Yu. Nikshikova reasons that this system was based on a holistic world perception which unites pedagogics and axiological forms of the culture learning, i.e. religion, moral, art and philosophy [Nikshikova, 2007]. According to an undivided opinion of many researchers, the choice of foreign languages in the pre-revolutionary Russia was directly determined by their practical importance. That is why in academies the languages of neighbours were learnt. Thus, V.E. Raushenbakh devotes much of his attention to the Oriental languages teaching, underlying that quite often private persons performed as founders of the required schools: that was a peculiar feature for the Siberian region, where people with a good command of the Oriental languages were in demand [Raushenbakh, 1971].

Just after the Revolution in 1917, foreign languages were taught mainly as an optional subject, that first of all was caused by severe deficiencies in teachers of foreign languages, since many of them had left the country. Still in 1927 foreign languages learning became a compulsory course in educational institutions of different levels. The country obtains specialized schools with advanced curriculum in foreign languages (German in particular). Since 1940s a strong scientific interest the questions of the history of foreign languages learning appeared in this country. As the result, there were a lot of scientific publications, articles, monographs and dissertations. Among others, works by V.D. Arakin, K.A. Ganshina, N.I. Gez and R.A. Kuznetsova who threw the light on a wide range of problems such as the analysis of purposes and intents of foreign languages learning, methodology of teaching, special aspects of speech activities teaching, historical and critical analysis of course books and study guides. Classification and analysis of the stored historical and pedagogical data conducted in different researches during the Soviet period of the history, has exerted material influence on the further development of the national linguistic education. The set of foreign languages to be learnt in the USSR was relatively small: people mainly learnt German, English and French during the whole Soviet period in Russia [Pavlenko, 2008]. 


\section{Foreign language acquisition} and linguistic personality development

The problems of the foreign languages learning (personal foreign languages learning) seen from a perspective of the content of "foreign" sign system acquisition can reasonably be concerned within the context of the modern linguistic concepts of personality: a linguistic, discursive and communicative one. In fact, being a personality (in its general scientific sense which implies the social and psychological characteristics of a subject), a man strikes a balance between all the above mentioned types of personality given in the linguistic light. Within the language science, a linguistic personality is understood as "the complex of human abilities and characteristics determining their creation and perception of texts, that vary in: a) the degree of structural and language complexity; b) the depth and precision of the reality reflection; c) a particular target [Karaulov, 1989: 3]. The most probable number of linguistic personalities for an individual is estimated by the sum of their basic linguistic personality which, as a rule, develops according to the circumstances of their birth and upbringing in the "native" linguistic and cultural environment, and the secondary linguistic personalities built as the result of the foreign language acquisition within the process of studying, self-education or living in a "foreign" culture. Having two or more linguistic personalities, one can simultaneously use several language systems. A communicative personality, in its turn, means a linguistic personality that communicates. A holder of the communicative personality comes in contact with other participants within the act of communication: this intends the implementation of a certain model of communicative behaviour and, thus, performs as an addressee or addresser of the message. The idea of a discursive personality also derives from the concept of linguistic personality and suggests creating of a particular discourse in the form of a specific message [Plotnikova, 2008a]. Following S.N. Plotnikova on the problem of the similarities and differences between the linguistic, discursive and communicative spheres, we conclude that an object of the foreign language education can have two or more linguistic personalities and only a single communicative one [Plotnikova 2008b: 135]. Active management principles of the work on foreign languages in universities namely contribute to the creation of a selfdeveloping personality. Initially, these principles are the permanency and continuation of foreign languages teaching in the system of pre-school, secondary and higher education. In universities these principles are implemented within the twotier system of teaching and under the system of extended education. The permanency and continuation in foreign languages training at different levels as well as through various learning paradigms, which are preferably structured on the basis of the universal complimentary principle (after Niels Bohr), support the progress in cognitive activity of students, create and train the self-developing linguistic personality that constantly requires foreign languages mastering under the professional cross-cultural communication. An important role in building of the secondary linguistic personalities is given to non-formal language learning.

Consequently, in modern Russia the process of foreign languages acquisition resulting in the development of one or two secondary linguistic personalities, is performed through a set of learning paradigms as well as at different educational levels. An extremely high demand for foreign languages in this country of the $21^{\text {st }}$ century is also particularly assured. Thus, there is a concrete need in the use of such knowledge both in personal and professional life of a person. Foreign language skills plays an important role in communication of people belonging to 
different cultures, nations or religions. With considerable distances can be covered at ease and against time, the contacts between the countries of the Europe and the world in general increase quantitative and, notably, qualitative ways. This situation applies to both personal and business relationships as well as touristic travelling. That is why foreign languages learning assumes more significance in the educational sphere in modern Russia. Linguistic skills not only allows us to communicate in all kinds of situations, but also assist in learning culture, history and traditions of overseas countries. A good command of one or more foreign languages has become an essential part of the job profile diagram of a successful specialist in a number of scientific and educational spheres as well as in industrial and business sectors. The problem of building an effective system for foreign languages education has now gained actuality both in national and international scales, what is apparently proved by the proceedings of scientific and methodological conferences, together with the research and development of methodic issues, conducted in this country and abroad. There is a plenty of course books, dictionaries, guidances, methods and academic programmes dedicated to foreign languages learning. Apparently, compiling of new programmes and advanced methods requires the knowledge and reflection of previous approaches and ways of foreign languages teaching as well as understanding them within different learning paradigms. One of such paradigms is the LLL paradigm appeared some three decades ago due to activities of UNESCO and the Council of Europe. To implement effectively this educational LLL strategy in the Russian educational space certain conditions were formed. One of the most significant factor is a clearly defined tendency to setting conditions and providing various opportunities for a person to meet their educational demands at three levels, i.e. at formal (formal learning), non-formal (non-formal learning) and so called informal (or informal learning). With that in this country national and international projects implemented under lifelong learning, are quite frequently aimed at formal institutionalization, and practically the only opportunity for that is given by the system of external professional education (EPE) designed for adult people. The new Russian Federation Law "On Education" among 34 main definition (Article 2) also contains the definition of external learning as a type of education oriented at an indepthmeeting educationaldemands in intellectual, moral and spiritual, physical and (or) professional self-improving that is not accompanied by the education degree rising. It is highly important that the human right in life long education is fixed in the Article 10, which, in particular, says that the education in the Russian Federation "is subdivided in general, professional, external education and professional training, providing with the opportunity to use the right in lifelong education (permanent education) [The Newest Federal Law, 2014: 16].

\section{The commodification of linguistic education within the era of globalization and globanglization}

Today a particular interest in linguistic educational space in this country is given to the English language that responds to present tendencies to globalization and globanlization (following in definition by V.V. Kabakchi). Concerning the globanglization as the dominance of the English language in different facets [Kabakchi, 2009; 2011], we can indicate cases of globanglization in the spheres of formal, nonformal and informal education.

So, the spheres of formal and non-formal education have a clear tendency to understanding the English language as a commodity that leads 
to concerns about the commodification of English as a foreign language. This commonly accepted term derives from the English word "commodity" (goods) and means the process of market relations interference into non-commercial spheres of the human activity or turning of originally unmarketed things into commodities.

The commodification is concerned to be a general tendency in education. Thus, recently educational processes in the world and in Russia in particular are marked by the evident tendency to commodification: the system of education is being transformed into the system of services, and the education itself is becoming a commodity. Being an element of the structural and institutional horizon? The education undergoes an increasingly greater engagement into the global processes together with the influence of two main tendencies, i.e. commercialization and unification. The commercialization and commodification (these concepts are used within the scientific discourse as synonyms or can be axiologically differentiated [Lebedeva, 2014]) of education represents a trend on its turning into one of the commodity types with all the specific characteristics, i.e. of a better or worse quality, introduced in a wide or limited range, cheap or expensive, etc. Educational institutions (particularly, professional ones) turns into a certain firms or corporations manufacturing and disposing educational services. In this way, students are considered as companies' customers or primary consumers of these goods (the secondary consumer is the society). The commodification of education presents the result of the globalizing liberal model of social and economic relations or the consequence of the contemporary social and historical revenge of the capital towards the society [Kardonova, 2007]. A Russian scientist, Alexander Karpov, concerns commodification (as well as commercialization) as a negative tendency in education and analyses it as a mechanism of the society destruction, "working" on the basis of knowledge. The researcher put the difference between the commodification of education and science and marks the policy and practise of their representation only in terms of commodity relations. According to his point of view, within the education performing as the system of services, the pursuance of understanding and interpretation of the human essence of the subject along with the intention to build an individual mental world and civic position are slaked. That kind of education destructs not only the growth points of the future but the society as a community itself [Karpov, 2013]. In his earlier works, the analyst expresses the same view as V.S. Nikolskii [Nikolskii, 2010] and claims that the conceptualization of education in the ideas of "commodity" and "service" excludes from its didactic ground the methods and matters that form a creative personality characterized by the research attitude to the reality, i.e. the personality able to generate knowledge. Thus, the protagonist of the society "working" on the basis of knowledge appears to be out of such a "commodity" vision. The commodifcation of cognitive activities that has turned the knowledge into a commodity, a thing for commercial use, changes the way the education is organized (bureaucracy) and understood (economical pragmatism and commercial mimesis) [Karpov, 2012]. Talking about the problems of commodificational policy in foreign educational sphere, the researcher highlights the fact that the history of commercialization in European education begins from the $13^{\text {th }}$ century when the academical trade of education and knowledge (which in that time belonged to the God) through teaching, nevertheless, received the supreme sanction of the Church [Karpov, 2012: 87]. Later, the commodification strategies in education were grounded basically on the English-American 
competitive model. American and European reforms of the higher education are implemented under the increase of academic contribution to the growth estimated only by commodity and monetary units.

Within the research field of economic sociology - a comparatively new branch of the science - commodification that initially was criticized, now has become the object for sociological studies aimed at analyzing the reasons for the suspicion of sociologists related to the commodification of crucial benefits; at describing methodological changes in the economic sociology against the backdrop of which the scientific interest to this problematics is risen; and at proposing the field of the topical research problems and directions [Berdysheva, 2012]. The literature survey taken up by S.V. Lebedeva shows that the term "commodification" is mainly used in the cases when authors focuses on the analysis and description of negative tendencies appearing within the contacts of business and scientific spheres: the corruption strengthened by the knowledge codification, the low quality of scientific researches in spin-off companies, the increasing amount of service functions performed by the science in the prejudice of independent studies [Lebedeva, 2014]. Along with a severe criticism of this phenomenon the modern scientific discourse also possesses a standpoint of smoothing the critics of commodification arising due to the acceptance by the economical sociology of the results obtained within the studies of the social origin of commodities. They are largely actualized within the framework of the economic anthropology, which is the main focus of economic sociologists under the process of a productive scientific dialog formation [Aspers, Darr, Kohl, 2011]. There is the understanding that commodification is much flexible and conditioned process and, thus, its potential can be wider and are not determined on the "yes" or "no" principle [Berdysheva, 2012: 74].

It is interesting to note that the consideration the English language as a good in modern Russia is not limited only by the Russian educational space. Thus, the language plays the same role in advertising texts (signs, labels, writings, designed magazines, etc), that is a direct consequence of globalization and globanglization.

As we see it, the English language commodification undoubtedly has both positive and negative effects. Thus, among the advantages we mark the independence of proposed linguistic academic programs and their increasing availability for different social classes and age groups. The educational service consumer is offered an opportunity of a wide range of choice, the right of which still depends on many aspects, i.e. the service quality control, administrative management through the procedures of accreditation and licensing of academic programs together with the social and mass media control.

\section{Conclusion}

The brief overview of the main tendencies in foreign language acquisition within the Russian educational space in synchronic and diachronic ways allows us to claim that the evident demand in a good command of foreign languages for personal and business purposes, the gathered international and national experience in foreign languages teaching and acquisition, the current levels in national education (they are formal, nonformal and informal) together with the network of educational institutions present or those which are under the construction, proves potential of the effective implementation of the LLL-paradigm. Both in short and long-term perspectives one can speak about the possibility of the specific LLLL (or Language Lifelong Learning) paradigm appearance: that means the linguistic education throughout the life which can directly inspire 
the future specialist to create several linguistic personalities. Possessing different linguistic personalities and having already built skills in cross-cultural communication, a polylingual professional will gain a high competitiveness within both the national and international scales; remarkably widen the part of international communication in their personal and business interaction. Misgivings about the risk for the native language can be completely influenced by the foreign one (the English language) are hardly well-reasoned. The creation of the secondary linguistic personality is undoubtedly can and should assist the development of the primary linguistic personality and personal characteristics in general.

\section{References}

Antologiia pedagogicheskoi mysli Rossii XVIII $v$ [The Anthology of Pedagogics in Russia on the $18^{\text {th }}$ century]. Moscow, Pedagogika, 1985. 480 p.

Aspers, P., Darr, A. \& Kolh, S. (2011). Ekonomiko-sociologicheskii vzgliad na ekonomicheskuiu antropologiu [An Economic Sociological Look at Economic Anthropology] Ekonomicheskaia sociologiia [Economic Sociology], 12(2), 126-136.

Berdysheva, E.S. (2012). Ot kritiki k analitike: kommodifikaciia zhiznenno vazhnyh blag kak aktual'naia issledovatel'skaia problema v novoi ekonomicheskoi sociologii [From Critics to Analytics: the Commodification of Crucial Goods as Topical Research Problem in New Economical Sociology]. Ekonomicheskaia sociologiia [Economical Sociology], 13(1), 67-85.

Kabakchi, V.V. Iazyk moi, kamo griadeshi? Globalizaciia, «globanglizaciia» i mezhkul'turnaia kommunikaciia [My Language, Whither Thou Goest? Globalization, "Gloabglization" and CrossCultural Communication]. Iazyk v paradigmah gumanitarnogo znaniia: XXI vek [The Language Through Paradigms of the Humanitarian Science: 21th century]. St-Petersburg, SPbGUEF, 2009. Pp. 78-97.

Kabakchi, V.V. Globalizaciia, «globanglizaciia» ili vtoraia volna bilingvizma v Rossii [Globalization, "Globanglization" or the Second Wave of Bilingualism in Russia]. Materialy XI mezhdunarodnoi nauchnoi konferencii po perevodovedeniiu «Fedorovskie chteniia» [The Proceedings of the XI International Scientific Conference on Translation Studies "Fedorov Readings"]. StPetersburg, 2011. Pp. 177-189.

Karaulov, Iu.N. Russkaia iazykovaia lichnost' i zadachi ee izucheniia [Russian Linguistic Personality and Tasks on its Analysis]. Iazyk i lichnost' [Language and Personality]. Moscow, Nauka, 1989. Pp.3-8.

Kardonova, I.A. Globalizaciia kak sociokul'turnaia transformaciia: instucional'naia perspektiva: avtoref. dis. ... kand. filosof. nauk [Globalization as the Social and Cultural Transformation: an institutional perspective: extended abstract of Ph.D. thesis in Philosophy]. Irkutsk, 2007. 22 p.

Karpov, A.O. (2012). Kommodifikaciia obrazovaniia v rakurse ego celei, ontologii i logiki kul'turnogo dvizheniia [The Commodification of Education from the Perspective of its Goals, Anthology and Logics of Cultural Movements]. Voprosy filosofii [Problems of Philosophy], 10, 85-96.

Karpov, A.O. Obrazovatel'nyi institut, vlast'i obshhestvo vepohu rosta kul' turyznanii [Educational Institution, Power and Society in the Era of the Cultural Knowledge Growth]. St-Petersburg, Aleteiia, 2013. $260 \mathrm{p}$. 
Lebedeva, S.V. Nauka i biznes: kommodifikaciia, kommercializaciia ili transfer tehnologii konferencii [The Science and Business: Commodification, Commercianalization or Technological Transfer]. Ekonomika i sovremennyi menedzhment: teoriia i praktika: sbornik statei po materialam XL mezhdunarodnoi nauchno-prakticheskoi [The Economy and Modern Management: the Theory and Practice. The Collection of Articles following the XL International Research and Practice Conference]. Novosibirsk, SibAK, 2014. Pp. 57-63.

Levchenko, O.Iu. (2013). Istoriograficheskii analiz prepodavaniia inostrannyh iazykov v Rossii [The Historiographical Analysis of Foreign Languages Teaching in Russia]. Gumanitarnyi vektor. Pedagogika, psihologiia [The Humanitarian Vector: Pedagogics, Psychology], 1(33), 31-35.

Nikol'skii, V.S. (2010). Kommodifikaciia znaniia i obrazovaniia [The Commodification of Knowledge and Education]. Vysshee obrazovanie v Rossii [Higher Education in Russia], 3, 149-152.

Nikshikova, L.Iu. Istoriko-pedagogicheskie osnovy prepodavaniia inostrannyh iazykov v Rossii XIX - nachala XX vekov: avtoref. diss. ... kand. ped. nauk. [Historical and Pedagogical Grounds in Foreign Language Teaching in Russia (the $19^{\text {th }}$ and the beginning of the $20^{\text {th }}$ centuries): extended abstract of Ph.D. thesis in Pedagogics]. Nizhnii Novgorod, 2007. 27 p,

Novyi Federal'nyi zakon "Ob obrazovanii v Rossiiskoi federacii» [The New Federal Law "On Education in the Russian Federation"]. Moscow, Prospekt, 2014. 160 p.

Pavlenko, A. Language management in the Russian empire, Soviet Union and post-Soviet countries. R.Bayley, R.Cameron, R\&S Lucas (eds). The Oxford Handbook of Sociolinguistics. Oxford University Press, 2013. Pp. 651-679.

Pavlenko, A. (2008). Multilingualism 1 in Post-Soviet Countries: Language Revival, Language Removal and Sociolinguistic Theory. The International Journal of Bilingual Education and Bilingualism, 11, Nos. 3\&4, 275- 314.

Plotnikova, S.N. (2008a). Govoriashhii/pishushhii kak iazykovaia, kommunikativnaia i diskursivnaia lichnost' [A Writing or Speaking Person as a Linguistic, Communicative or Discursive Personality]. Vestnik Nizhnevartovskogo gosudarstvennogo gumanitarnogo universiteta [Journal of Nizhnevartovsk State University for the Humanities], 4, 37-42.

Plotnikova, S.N. (2008b). Iazykovoe, diskursivnoe i kommunikativnoe prostranstvo [The Linguistic, Discursive and Communicative Spaces]. Vestnik Irkutskogo gosudarstvennogo lingvisticheskogo universiteta [Journal of Irkutsk State Linguistic University], 1, 131-136.

Raushenbakh, V.Ie. Kratkii obzor osnovnyh metodov prepodavaniia inostrannyh iazykov s I po $X X$ vek [A Review of the Main Methods of Foreign Languages Teaching from the $1^{\text {st }}$ to $20^{\text {th }}$ centuries]. Moscow, Vysshaia shkola, 1971. 112 p.

Solodiankina, O. Iu. Inostrannye nastavniki $v$ dvorianskom domashnem vospitanii $v$ Rossii (vtoraia polovina XVIII - pervaia polovina XIX v.): avtoref. dis. ... d-ra ist. nauk [Foreign Tutors in Home Education of Noble Children in Russia (the second half of the $18^{\text {th }}$ and the first half of the $19^{\text {th }}$ centuries): extended abstract of Ph.D. thesis in History]. Moscow, 2008. 34 p.

Ushinskii, K.D. Pedagogicheskie sochineniia [Essays on Pedagogics].V. 2. Moscow, Pedagogika, 1988. $496 \mathrm{p}$. 


\title{
Коммодификация иностранных языков
}

\author{
В.А. Разумовская \\ Сибирский федеральный университет \\ Россия, 660041, Красноярск, пр. Свободньй, 79
}

В статье в диахронной и синхронной перспективах рассматриваются преподавание и изучение иностранных языков в образовательном пространстве России. Особое внимание уделяется английскому языку как иностранному (EFL), бытование которого в различных образовательных парадигмах анализируется в терминах глобанглизачии и коммодификачии образовательных услуг. Описываются положительные и отрицательные аспекты коммодификации языкового образования и перспективы развития парадигмы лингвистического образования в течение всей жизни (Language Lifelong Learning).

Ключевые слова: иноязычное образование, обучение в течение всей жизни, английский язык, глобанглизачия, коммодификация.

Статья написана при финансовой поддержке гранта программь ТЕМПУС IV Европейского Союза (проект «Создание сети университетских языковых центров для профессионального и личностного развития человека в рамках парадигмы «образование в течение всей жизни», № 544283-TEMPUS-1-2013-1-ES-TEMPUS-JPHES).

Научная специальность: 13.00.00 - педагогические науки, 10.00.00 - филологические науки. 